\title{
Health education: the effectiveness of interventions in patients with heart failure
}

\author{
Educação em saúde: efetividade das intervenções em pacientes com insuficiência cardíaca
}

Educación para la salud: la efectividad de las intervenciones en pacientes con insuficiencia cardíaca

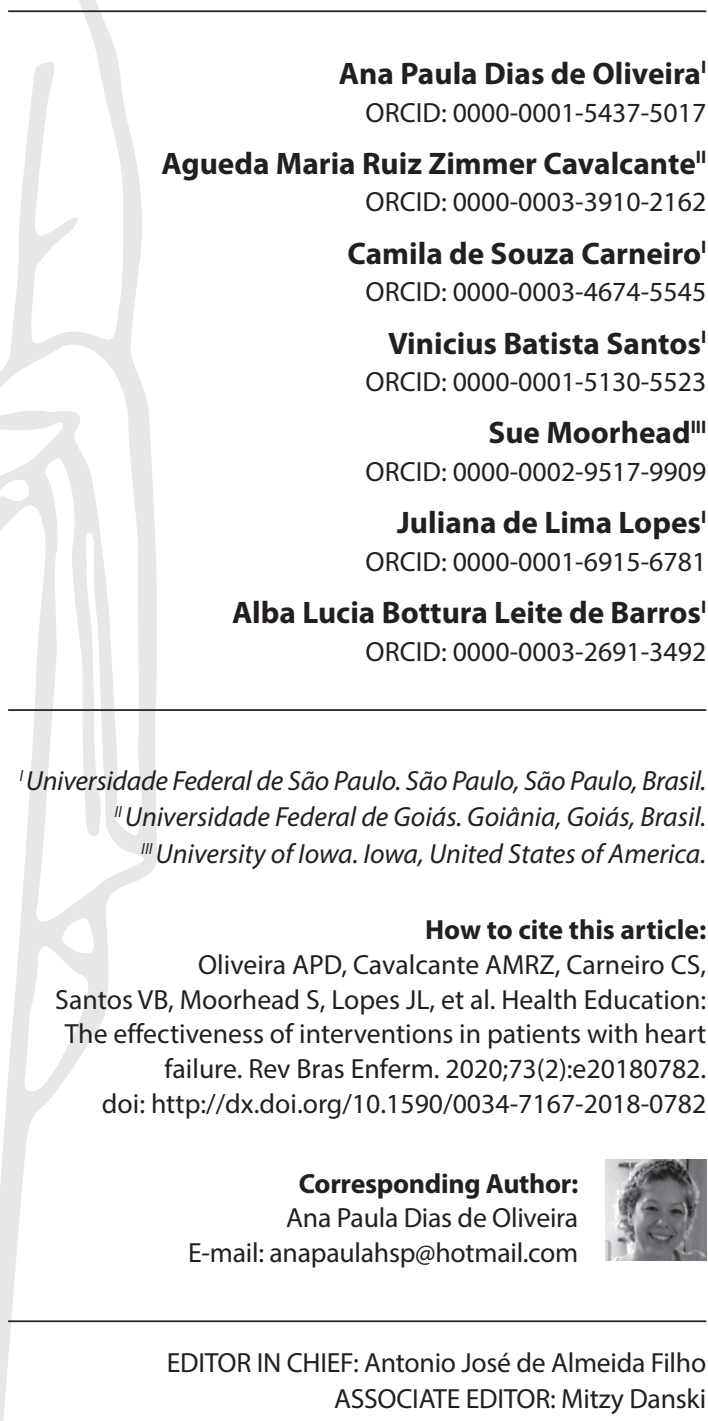

Submission: 10-11-2018

Approval: 04-26-2019

\section{ABSTRACT}

Objectives: To evaluate the effectiveness of NIC interventions "Teaching: Disease Process", "Health Education" and "Cardiac Care" in the improvement of NOC results in individuals with Heart Failure (HF), and the Nursing Diagnosis (ND) "Ineffective Health Control". Methods: Retrospective cohort, conducted at a Health Education in Nursing outpatient clinic. Fourteen patients with HF had follow-up for one year in six bimonthly consultations. The effectiveness of interventions was verified through the change of the result scores through the Friedman's Non-Parametric Test and Analysis of Non-Parametric Variance for repeated measures. The level of significance was $5 \%$. Results: The interventions were implemented in consultations in a variety of activities. There was a significant improvement in the result scores until the fourth visit $(p<0.001)$. Conclusions: The interventions were effective in improving outcomes in patients with HF and Ineffective Health Control.

Descriptors: Health Education; Nursing Education; Effectiveness; Cardiac Insufficiency; Nursing Diagnosis.

\section{RESUMO}

Objetivos: Avaliar a efetividade das intervenções NIC "Ensino: Processo de Doença”, “Educação em Saúde" e "Cuidados Cardíacos" na melhora de resultados NOC em indivíduos com Insuficiência Cardíaca (IC), e o Diagnóstico de Enfermagem (DE) "Controle Ineficaz da Saúde". Métodos: Coorte retrospectivo, conduzido num ambulatório de enfermagem de Educação em Saúde. Foram incluídos 14 pacientes com IC acompanhados durante um ano em seis consultas presenciais bimestrais. A efetividade das intervenções foi verificada por meio da mudança dos escores dos resultados por meio dos Testes Não-Paramétricos de Friedman e Análise de Variância Não-Paramétrica para medidas repetidas. O nível de significância adotado foi de 5\%. Resultados: As intervenções foram implementadas nas consultas com variação das atividades. Houve melhora significativa dos escores dos resultados até a quarta consulta $(p<0,001)$. Conclusões: As intervenções foram efetivas na melhora dos resultados em pacientes com IC e no Controle Ineficaz da Saúde.

Descritores: Educação em Saúde; Educação em Enfermagem; Efetividade; Insuficiência Cardíaca; Diagnóstico de Enfermagem.

\section{RESUMEN}

Objetivos: Evaluar la efectividad de las intervenciones NIC "Enseñanza: Proceso de Enfermedad", "Educación para la Salud" y "Cuidados Cardíacos" en la mejora de resultados NOC en individuos con insuficiencia cardíaca (IC) y el diagnóstico de enfermería (DE) "Control Ineficaz de la Salud". Métodos: Ccohorte retrospectivo conducido en un ambulatorio de enfermería de educación para la Salud. Se incluyeron 14 pacientes con IC acompañados durante un año, en seis consultas presenciales bimestrales. La efectividad de las intervenciones fue verificada por medio del cambio de los escores de los resultados, con uso de las Pruebas no paramétricas de Friedman y Análisis de Variancia no Paramétrica para medidas repetidas. El nivel de significancia adoptado fue del 5\%. Resultados: Llas intervenciones fueron implementadas en las consultas con variación de las actividades. Se observó una mejoría significativa de los resultados obtenidos hasta la cuarta consulta $(p<0,001)$. Conclusiones: Llas intervenciones fueron efectivas en la mejora de los resultados en pacientes con IC y Control Ineficaz de la Salud.

Descriptores: Educación para la Salud; Educación en Enfermería; Efectividad; Insuficiencia Cardíaca; Diagnóstico de Enfermería. 


\section{INTRODUCTION}

Heart Failure is a serious public health problem, especially in the group of chronic diseases, due to a high mortality rate, frequent hospitalizations, poor quality of life and deterioration of the organic functions, leading to an incapacity of self-care $(\mathrm{SC})^{(1)}$. Changing inadequate life habits, according to the recommendations established by health professionals, can ensure the control of HF and maintenance of health, with a positive impact on clinical outcomes ${ }^{(2)}$.

The process of Health Education is usually attributed to nurses who, during the clinical evaluation of patients, must identify real and potential problems, develop a plan of care that is adequate and contributes to the promotion, maintenance and recovery of health. This scientific method, led by nurses, when counting with standardized classifications, assists in the development of the language and vocabulary of Nursing, in the organization of critical thinking and diagnostic reasoning, besides contributing to the achievement of the Evidence-based practice ${ }^{(3)}$.

The programs of chronic disease education and control have shown to be effective, including patients with $\mathrm{HF}^{(4)}$, with positive results in reducing the days of hospitalization, rehospitalization and quality of life. However, studies evaluating effectiveness using NANDA-l-related Nursing Interventions Classifications (NICs) and evaluated through the NOC Classification of results are still incipient in the literature ${ }^{(5)}$.

The ND "Ineffective Health Control" is defined as "Standard of regulation and integration to the daily life of a therapy to treat diseases and their sequelae, unsatisfactory in achieving the specific health goals"(6). This diagnosis is closely related to those individuals who present clinical phenomena with clear implications for the Nursing practice and that require specific SC actions. These actions are described in three distinct and interrelated processes of maintenance, symptomatic perception and management ${ }^{(7)}$.

The frequent need for re-hospitalization is directly related to the difficulty in the control and management of the disease by patients and a consequent poor compliance with the basic therapy for $\mathrm{HF}^{(8)}$. In this overview, disease management programs are widely used in the care of patients with HF and are organized around principles that aim to improve the patient's knowledge and skills to perform SC tasks and manage their health condition. They have elements such as: encouragement of the monitoring of signs/symptoms; education in problem solving skills; and improved compliance with medical treatment, physical activity, diet, cessation of smoking, among others ${ }^{(2)}$.

The NIC interventions "Teaching: Disease Process", "Health Education" and "Cardiac Care" present activities whose contents correspond to the interventions used in the Programs of Disease Management. These activities can be directed to patients who present different concepts related to SC, and can be evaluated by some NOC results related to this phenomenon ${ }^{(9)}$. Therefore, the use of Nursing classification systems in the care of patients with HF can contribute to the visualization of the patient's improvement, the direction of individualized nursing planning, as well as the improvement of the standardized languages.

\section{OBJECTIVES}

This study aims to evaluate the effectiveness of NIC interventions "Teaching: Disease Process", "Health Education" and "Cardiac
Care" for patients with HF and the "Ineffective Health Control", served in an outpatient clinic.

\section{METHODS}

\section{Ethical aspects}

The research project was evaluated and approved by the Research Ethics Committee (Comissão de Ética em Pesquisa-CEP) of UNIFESP/HSP. Considering this is a retrospective study and that data collection occurred in medical records, there was no need to sign the Free and Informed Consent Form.

\section{Design, study location and period}

This is a retrospective cohort study carried out at the Health Education in Nursing Outpatient Clinic, which is linked to a Hospital and Teaching Institution of a large city in Brazil. Patients were referred by the doctor's office or hospital as one of the hospital discharge guidelines. The study period was 1 year.

\section{Population or sample; inclusion and exclusion criteria}

A total of 14 medical records of patients accompanied in the outpatient clinic. Patients needed the following characteristics: being over 18; presenting the medical diagnosis of HF in stages C or D of the American College of Cardiology, given they are the clinical manifestation stages of the disease ${ }^{(10)}$; having the "Ineffective Health Control" ND identified by two nurses at the time of the consultation and; having attended to six bimonthly presential consultations during one year interspersed with phone consultations. The records of patients that did not contain information on all analyzed variables were excluded.

\section{Study protocol}

Outpatient visits were performed by cardiac nurses with clinical experience and knowledge in the area of standardized languages.

The NIC interventions "Teaching: Disease Process", "Cardiac Care" and "Health Education", the NOC results "Self-control of Heart Disease" and "Compliance Behavior", used during the Nursing consultation were selected from the consensus within the group of studies in Systematization of Nursing Assistance at the Federal University of São Paulo (Universidade Federal de São Paulo - USP) and professors at the Nursing faculty from the University of lowa, USA, participants of the study. Such indicators are commonly used in patients with HF in disease management programs ${ }^{(4,11)}$.

In-person consultations were interspersed with phone consultations for all patients and used the health status assessment model, reinforcement of guidelines and clarification of doubts. Chart 1 shows the model of the educational program carried out by the nurses from the Health Education Outpatient Clinic.

The first consultation lasted approximately two hours, and the subsequent consultations took about an hour and a half, due to the qualified listening ${ }^{(12)}$ and the interaction with relatives and companions, who participated actively in the educational activities carried out by nurses. 
Chart 1 - Description of the Health Education in Nursing Outpatient Clinic, São Paulo, São Paulo, Brazil, 2017

\begin{tabular}{|c|c|c|c|c|c|}
\hline Consultation & Steps Held & Interventions & Nursing actions & Evaluation & Duration \\
\hline Consultation 1 & $\begin{array}{l}\text { 1. Interview/Patients' } \\
\text { anamnesis and physical } \\
\text { examination; } \\
\text { 2. Confirmation of Ineffective } \\
\text { Health Control ND, CD and } \\
\text { FR; } \\
\text { 3. Documentation on specific } \\
\text { instruments. }\end{array}$ & $\begin{array}{l}\text { Implementation } \\
\text { of intervention } \\
\text { activities: } \\
\text { - Education: Disease } \\
\text { Process } \\
\text { - Heart Care } \\
\text { - Health Education. }\end{array}$ & $\begin{array}{l}\text { 1. To offer guidance about the } \\
\text { disease, non-pharmacological and } \\
\text { pharmacological treatment; } \\
\text { 2. To present the website developed } \\
\text { by the outpatient clinic group of } \\
\text { researchers; } \\
\text { 3. To provide informative material* } \\
\text { (individual guidelines regarding } \\
\text { medications prescribed by the doctor, } \\
\text { appointments and purposes of each; } \\
\text { adequate diet, fluid restriction, water } \\
\text { content of the main foods ingested by } \\
\text { the Brazilian population); }\end{array}$ & $\begin{array}{l}\text { Evaluation of NOC } \\
\text { results indicators: } \\
\text { Self-control of } \\
\text { Heart Disease, } \\
\text { Compliance } \\
\text { Behavior. }\end{array}$ & $2 \mathrm{~h}$ \\
\hline $\begin{array}{l}\text { Telephone } \\
\text { consultation }\end{array}$ & $\begin{array}{l}\text { 1. Identification of the } \\
\text { patient's health condition; } \\
\text { 2. Identification of emerging } \\
\text { needs and compliance with } \\
\text { treatment. }\end{array}$ & $\begin{array}{l}\text { Implementation } \\
\text { of intervention } \\
\text { activities: } \\
\text { - Education: Disease } \\
\text { Process } \\
\text { - Heart Care } \\
\text { - Health Education. }\end{array}$ & $\begin{array}{l}\text { 1. To check the difficulties with the } \\
\text { therapeutic regimen; } \\
\text { 2. To check the degree of knowledge } \\
\text { about the disease and treatment } \\
\text { acquired in the previous consultation; } \\
\text { 3. To verify patient compliance with the } \\
\text { guidelines received. }\end{array}$ & $\begin{array}{l}\text { 1. Presence of signs } \\
\text { and symptoms } \\
\text { described by } \\
\text { the patient } \\
\text { and suggestive } \\
\text { of clinical } \\
\text { decompensation. }\end{array}$ & $15 \mathrm{~min}$ \\
\hline $\begin{array}{l}\text { Other } \\
\text { Consultations }\end{array}$ & $\begin{array}{l}\text { 1. Physical Examination; } \\
\text { 2. CD and FR re-evaluation; } \\
\text { 3. Clarification of current } \\
\text { doubts and difficulties } \\
\text { reported by patients; } \\
\text { 3. Pointing solutions or } \\
\text { improvements; } \\
\text { 4. Verification of knowledge } \\
\text { of the disease and treatment, } \\
\text { and knowledge gaps. }\end{array}$ & $\begin{array}{l}\text { Implementation } \\
\text { of intervention } \\
\text { activities: } \\
\text { - Education: Disease } \\
\text { Process } \\
\text { - Heart Care } \\
\text { - Health Education. }\end{array}$ & $\begin{array}{l}\text { 1. To reorientate on the disease, non- } \\
\text { pharmacological and pharmacological } \\
\text { treatment (identification of knowledge } \\
\text { gaps for reinforcement); } \\
\text { 2. To check patient compliance with given } \\
\text { instructions; } \\
\text { 3. To verify the difficulties regarding the } \\
\text { therapeutic regime and to establish } \\
\text { strategies to overcome difficulties; } \\
\text { 4. To assess and identify signs of } \\
\text { decompensation. }\end{array}$ & $\begin{array}{l}\text { Evaluation of NOC } \\
\text { results indicators: } \\
\text { Self-control of } \\
\text { Heart Disease, } \\
\text { Adhesion } \\
\text { Behavior. }\end{array}$ & $1 \mathrm{~h} 30 \mathrm{~min}$ \\
\hline
\end{tabular}

Note: *All printed informative material was developed by the study and research group, and was used during the consultations and given to patients and their companions.

Chart 2 - Indicators of the NOC results "Self-control of Heart Disease" and "Compliance Behavior", selected to evaluate the effectiveness of the implementation of Nursing interventions "Disease Process", "Cardiac Care" and "Health Education", São Paulo, São Paulo, Brazil, 2017

\begin{tabular}{|l|l|}
\hline Nursing results & Clinical indicators assessed \\
\hline $\begin{array}{l}\text { Self-control of } \\
\text { Heart Disease }\end{array}$ & $\begin{array}{l}\text { 1. Limits sodium intake } \\
\text { 2. Follows the recommendation regarding fluid restriction } \\
\text { 3. Monitors body weight } \\
\text { 4. Maintains an ideal weight } \\
\text { 5. Uses medication as prescribed } \\
\text { 6. Is vaccinated against influenza (flu) } \\
\text { 7. Is vaccinated against pneumonia }\end{array}$ \\
\hline $\begin{array}{l}\text { Compliance } \\
\text { Behavior }\end{array}$ & $\begin{array}{l}\text { 1. Asks questions about health } \\
\text { 2. Weighs risks/benefits regarding health behavior } \\
\text { 3. Uses strategies to eliminate unhealthy behavior } \\
\text { 4. Justifies deviating from a health diet } \\
\text { 5. Performs self-monitoring of health condition }\end{array}$ \\
\hline
\end{tabular}

In the first face-to-face consultation, all activities of the three NIC interventions selected for all patients were implemented. In the subsequent in-person and phone consultations, only the activities of the needed NIC interventions were implemented, according to the problems identified by nurses or reported by patients or their companions.

The effectiveness of the NIC interventions was analyzed through the evaluation during the face-to-face consultations of two NOC results "Self-control of Heart Disease" and "Compliance Behavior", which present respectively 44 and 13 indicators. However, 7 and 5 NOC indicators were selected by the study group, respectively, for a total of twelve indicators, as they were in compliance with the recommendations described by the Brazilian Society of Cardiology (Sociedade Brasileira de Cardiologia) ${ }^{(10)}$, by the European Society of Cardiology ${ }^{(13)}$ and the American Heart Association ${ }^{(14)}$. The two nursing outcomes and their indicators are presented in Chart 2.

These indicators were considered outcome variables, which were attributed for each indicator at the end of every in-person consultation with a score ranging from 1 (never demonstrated), 2 (rarely demonstrated), 3 (often demonstrated), 4 (frequently demonstrated), and 5 (consistently demonstrated).

\section{Analysis of results and statistics}

The data were collected from instruments records used during the nursing consultations and inserted into a spreadsheet on Microsoft Office Excel ${ }^{\circ} 2010$. The statistical program used for analysis was the Statistical Package for the Social Sciences ${ }^{\circ}$ (SPSS), version 19.0 and software $R$.

A descriptive analysis of patients was performed, considering the variables of interest. Data were presented using absolute (n) and relative (\%) frequencies for categorical variables, as well as mean and standard deviation (SD) for continuous variables.

The evaluations of the indicators of the results of each consultation were described by absolute and relative frequencies. For analyzing the effectiveness of each indicator, the NOC results, the Friedman's Non-Parametric Test was used, considering the sample size. 
For the analysis of effectiveness of nursing interventions, the Final Score was calculated by summing the seven indicators of the "Self-control of Heart Disease" result and the five indicators of the "Compliance Behavior" result. Considering the total selection of 12 indicators and that each indicator had 5 levels, the Final Score of each patient could assume values that varied between 12 and 60 points. To analyze the variance between the pairs of consultations, the non-parametric ANOVA Test was performed with the method of comparison of via matrices of contrasts. The significance level was $5 \%$.

\section{RESULTS}

Fourteen medical records of patients with HF were monitored during a one-year period, totaling 6 face-to-face consultations and 6 phone consultations performed in an intercalated fashion.
The majority were male $(n=9)$, with a mean age of $60.4 \pm 13$, active $(n=7)$, married or with a partner $(n=7)$, family income ranging from 1 to 3 minimum wages $(n=6)$.

Ischemic heart disease $(n=5)$ and hypertensive heart disease $(n=4)$ were the most prevalent etiologies. The most frequent comorbidities included hypertension $(n=11)$ and coronary insufficiency $(n=10)$. Most patients were classified as stage $C$ of HF evolution $(n=14)$.

Table 1 shows the evolution of the seven indicators from the NOC result "Self-control of Heart Disease", selected in the evaluation of patients. The indicators "Is Vaccinated Against Influenza (Flu)" and "Is Vaccinated Against Pneumonia" are presented by the NOC as indicators but are evaluated individually to identify compliance with both vaccines. Table 2 shows the evolution of the selected indicators from the NOC result "Compliance Behavior".

Table 1 - Frequency of indicators Nursing Outcomes Classification of the result "Self-control of Heart Disease" selected for evaluating patients with HF, followed up at the Health Education Outpatient Clinic in Cardiology, for one year, São Paulo, São Paulo, Brazil, 2017

\begin{tabular}{|c|c|c|c|c|c|c|c|c|}
\hline & & $\begin{array}{c}\text { Consultation } \\
1 \\
\text { n (\%) }\end{array}$ & $\begin{array}{c}\text { Consultation } \\
\mathbf{2} \\
\mathbf{n}(\%)\end{array}$ & $\begin{array}{c}\text { Consultation } \\
\mathbf{3} \\
\mathbf{n}(\%)\end{array}$ & $\begin{array}{c}\text { Consultation } \\
4 \\
n(\%)\end{array}$ & $\begin{array}{c}\text { Consultation } \\
\mathbf{5} \\
\mathbf{n}(\%)\end{array}$ & $\begin{array}{c}\text { Consultation } \\
6 \\
\text { n (\%) }\end{array}$ & $\underset{\text { value* }}{p}$ \\
\hline \multirow{5}{*}{$\begin{array}{l}\text { Limits sodium } \\
\text { intake }\end{array}$} & Never demonstrated & $2(14.2)$ & $1(7.1)$ & 0 & 0 & $1(7.1)$ & 0 & \multirow{5}{*}{$<0.00$} \\
\hline & Rarely demonstrated & $3(21.4)$ & $1(7.1)$ & $1(7.10$ & 0 & 0 & $2(14.2)$ & \\
\hline & Sometimes demonstrated & $6(42.8)$ & $6(42.8)$ & $1(7.1)$ & $3(21.4)$ & $3(21.4)$ & $2(14.2)$ & \\
\hline & Often demonstrated & $2(14.2)$ & $3(21.4)$ & $5(35.7)$ & $3(21.4)$ & $4(28.5)$ & $4(28.5)$ & \\
\hline & Consistently demonstrated & $1(7.1)$ & $3(21.4)$ & $7(50.0)$ & $8(57.1)$ & $6(42.8)$ & $6(42.8)$ & \\
\hline \multirow{5}{*}{$\begin{array}{l}\text { Complies with the } \\
\text { recommendation } \\
\text { regarding fluid } \\
\text { restriction }\end{array}$} & Never demonstrated & 0 & 0 & $1(7.1)$ & $2(14.2)$ & $2(14.2)$ & 0 & \multirow{5}{*}{0.050} \\
\hline & Rarely demonstrated & $4(28.5)$ & $2(14.2)$ & 0 & $1(7.1)$ & $2(14.2)$ & $2(14.2)$ & \\
\hline & Sometimes demonstrated & $6(42.8)$ & $8(57.1)$ & $6(42.8)$ & $1(7.1)$ & $1(7.1)$ & $3(21.4)$ & \\
\hline & Often demonstrated & $4(28.5)$ & $2(14.2)$ & $1(7.1)$ & $1(7.1)$ & $2(14.2)$ & $4(28.5)$ & \\
\hline & Consistently demonstrated & 0 & $2(14.2)$ & $6(42.8)$ & $9(64.2)$ & $7(50.0)$ & $5(35.7)$ & \\
\hline \multirow{5}{*}{$\begin{array}{l}\text { Monitors body } \\
\text { weight }\end{array}$} & Never demonstrated & $1(7.1)$ & $2(14.2)$ & $1(7.1)$ & $1(7.1)$ & 0 & 0 & \multirow{5}{*}{0.059} \\
\hline & Rarely demonstrated & $5(35.7)$ & $2(14.2)$ & $1(7.1)$ & $2(14.2)$ & $1(7.1)$ & $1(7.1)$ & \\
\hline & Sometimes demonstrated & $3(21.4)$ & $3(21.4)$ & $4(28.5)$ & $2(14.2)$ & $2(14.2)$ & 0 & \\
\hline & Often demonstrated & $4(28.5)$ & $3(21.4)$ & $3(21.4)$ & $2(14.2)$ & $5(35.7)$ & $5(35.7)$ & \\
\hline & Consistently demonstrated & $1(7.1)$ & $4(28.5)$ & $5(35.7)$ & $7(50.0)$ & $6(42.8)$ & $8(57.1)$ & \\
\hline \multirow{5}{*}{$\begin{array}{l}\text { Maintains an ideal } \\
\text { weight }\end{array}$} & Never demonstrated & $1(7.1)$ & $2(14.2)$ & $1(7.1)$ & $1(7.1)$ & $1(7.1)$ & 0 & \multirow{5}{*}{0.012} \\
\hline & Rarely demonstrated & $2(14.2)$ & $2(14.2)$ & $2(14.2)$ & $1(7.1)$ & $2(14.2)$ & $1(7.1)$ & \\
\hline & Sometimes demonstrated & $2(14.2)$ & $2(14.2)$ & 0 & $2(14.2)$ & 0 & $1(7.1)$ & \\
\hline & Often demonstrated & $5(35.7)$ & $4(28.5)$ & $6(42.8)$ & $5(35.7)$ & $4(28.5)$ & $3(21.4)$ & \\
\hline & Consistently demonstrated & $4(28.5)$ & $4(28.5)$ & $5(35.7)$ & $5(35.7)$ & $7(50.0)$ & $9(64.2)$ & \\
\hline \multirow{5}{*}{$\begin{array}{l}\text { Uses medication as } \\
\text { prescribed }\end{array}$} & Never demonstrated & $1(7.1)$ & 0 & 0 & 0 & 0 & 0 & \multirow{5}{*}{0.014} \\
\hline & Rarely demonstrated & $1(7.1)$ & $1(7.1)$ & $1(7.1)$ & $1(7.1)$ & $1(7.1)$ & 0 & \\
\hline & Sometimes demonstrated & $4(28.5)$ & $2(14.2)$ & $3(21.4)$ & $1(7.1)$ & $1(7.1)$ & 0 & \\
\hline & Often demonstrated & $5(35.7)$ & $7(50.0)$ & $3(21.4)$ & $4(28.5)$ & $2(14.2)$ & $2(14.2)$ & \\
\hline & Consistently demonstrated & $3(21.4)$ & $4(28.5)$ & $7(50.0)$ & $8(57.1)$ & $10(71.4)$ & $12(85.7)$ & \\
\hline \multirow{5}{*}{$\begin{array}{l}\text { Is vaccinated } \\
\text { against influenza } \\
\text { (flu) }\end{array}$} & Never demonstrated & $4(28.5)$ & $2(14.2)$ & $3(21.4)$ & $2(14.2)$ & $1(7.1)$ & $1(7.1)$ & \multirow{5}{*}{0.001} \\
\hline & Rarely demonstrated & 0 & 0 & 0 & 0 & 0 & 0 & \\
\hline & Sometimes demonstrated & $3(21.4)$ & $1(7.1)$ & $1(7.1)$ & 0 & 0 & 0 & \\
\hline & Often demonstrated & $3(21.4)$ & 0 & 0 & $1(7.1)$ & 0 & 0 & \\
\hline & Consistently demonstrated & $4(28.5)$ & $11(78.5)$ & $10(71.4)$ & $11(78.5)$ & $13(92.8)$ & $13(92.8)$ & \\
\hline \multirow{5}{*}{$\begin{array}{l}\text { Is vaccinated } \\
\text { against pneumonia }\end{array}$} & Never demonstrated & $7(50.0)$ & $2(14.2)$ & $2(14.2)$ & $2(14.2)$ & $1(7.1)$ & 0 & \multirow{5}{*}{0.001} \\
\hline & Rarely demonstrated & 0 & 0 & 0 & 0 & 0 & 0 & \\
\hline & Sometimes demonstrated & $3(21.4)$ & $1(7.1)$ & $1(7.1)$ & 0 & 0 & 0 & \\
\hline & Often demonstrated & $3(21.4)$ & 0 & 0 & 0 & 0 & 0 & \\
\hline & Consistently demonstrated & $1(7.1)$ & $11(78.5)$ & 11 & 12 & $13(92.8)$ & $14(100.0)$ & \\
\hline
\end{tabular}

Note: *Teste de Friedman. 
Table 2 - Frequency of indicators Nursing Outcomes Classification (NOC) of the result "Self-control of Heart Disease" selected for evaluating patients with HF, followed up at the Health Education Outpatient Clinic in Cardiology, for one year, São Paulo, São Paulo, Brazil, 2017

\begin{tabular}{|c|c|c|c|c|c|c|c|c|}
\hline & & $\begin{array}{c}\text { Consultation } \\
1 \\
\text { n (\%) }\end{array}$ & $\begin{array}{c}\text { Consultation } \\
2 \\
\text { n (\%) }\end{array}$ & $\begin{array}{c}\text { Consultation } \\
\mathbf{3} \\
\mathbf{n}(\%)\end{array}$ & $\begin{array}{c}\text { Consultation } \\
\mathbf{4} \\
\mathbf{n}(\%)\end{array}$ & $\begin{array}{c}\text { Consultation } \\
\mathbf{5} \\
\mathbf{n}(\%)\end{array}$ & $\begin{array}{c}\text { Consultation } \\
6 \\
\text { n (\%) }\end{array}$ & $\begin{array}{c}p \\
\text { value* }\end{array}$ \\
\hline \multirow{5}{*}{$\begin{array}{l}\text { Asks questions } \\
\text { about health }\end{array}$} & Never demonstrated & 0 & 0 & 0 & 0 & 0 & 0 & \multirow{5}{*}{$<0.001$} \\
\hline & Rarely demonstrated & $3(21.4)$ & $3(21.4)$ & $1(7.1)$ & 0 & 0 & 0 & \\
\hline & Sometimes demonstrated & $3(21.4)$ & $1(7.1)$ & $2(14.2)$ & $1(7.1)$ & $1(7.1)$ & 0 & \\
\hline & Often demonstrated & $3(21.4)$ & $5(35.7)$ & $4(28.5)$ & $4(28.5)$ & $2(14.2)$ & $1(7.1)$ & \\
\hline & Consistently demonstrated & $5(35.7)$ & $5(35.7)$ & $7(50.0)$ & $9(64.2)$ & $11(78.5)$ & $13(92.8)$ & \\
\hline \multirow{5}{*}{$\begin{array}{l}\text { Weighs risks/ } \\
\text { benefits regarding } \\
\text { health behavior }\end{array}$} & Never demonstrated & 0 & 0 & 0 & 0 & 0 & 0 & \multirow{5}{*}{0.003} \\
\hline & Rarely demonstrated & $5(35.7)$ & $2(14.2)$ & 0 & 0 & $2(14.2)$ & 0 & \\
\hline & Sometimes demonstrated & $2(14.2)$ & $5(35.7)$ & $4(28.5)$ & $2(14.2)$ & 0 & $2(14.2)$ & \\
\hline & Often demonstrated & $4(28.5)$ & $3(21.4)$ & $5(35.7)$ & $6(42.8)$ & $5(35.7)$ & $5(35.7)$ & \\
\hline & Consistently demonstrated & $3(21.4)$ & $4(28.5)$ & $5(35.7)$ & $6(42.8)$ & $7(50.0)$ & $7(50.0)$ & \\
\hline \multirow{5}{*}{$\begin{array}{l}\text { Uses strategies } \\
\text { to eliminate } \\
\text { unhealthy } \\
\text { behavior }\end{array}$} & Never demonstrated & 0 & 0 & 0 & $1(7.1)$ & 0 & 0 & \multirow{5}{*}{0.128} \\
\hline & Rarely demonstrated & $4(28.5)$ & $1(7.1)$ & $1(7.14)$ & 0 & $3(21.4)$ & $2(14.2)$ & \\
\hline & Sometimes demonstrated & $6(42.8)$ & $7(50.0)$ & $5(35.7)$ & $3(21.4)$ & $2(14.2)$ & $2(14.2)$ & \\
\hline & Often demonstrated & $1(7.1)$ & $4(28.5)$ & $4(28.5)$ & $3(21.4)$ & $1(7.14)$ & $4(28.5)$ & \\
\hline & Consistently demonstrated & $3(21.4)$ & $2(14.2)$ & $4(28.5)$ & $7(50.0)$ & $8(57.1)$ & $6(42.8)$ & \\
\hline \multirow{5}{*}{$\begin{array}{l}\text { Justifies deviating } \\
\text { from a health diet }\end{array}$} & Never demonstrated & $2(14.2)$ & $2(14.2)$ & $1(7.1)$ & $1(7.1)$ & $2(14.2)$ & $2(14.2)$ & \multirow{5}{*}{0.013} \\
\hline & Rarely demonstrated & $7(50.0)$ & $3(21.4)$ & 0 & $2(14.2)$ & $2(14.2)$ & $1(7.1)$ & \\
\hline & Sometimes demonstrated & $3(21.4)$ & $5(35.7)$ & $7(50.0)$ & $2(14.2)$ & $3(21.4)$ & $4(28.5)$ & \\
\hline & Often demonstrated & $1(7.1)$ & $3(21.4)$ & $2(14.2)$ & $5(35.7)$ & $2(14.2)$ & $2(14.2)$ & \\
\hline & Consistently demonstrated & $1(7.1)$ & $1(7.1)$ & $4(28.5)$ & $4(28.5)$ & $5(35.7)$ & $5(35.7)$ & \\
\hline \multirow{5}{*}{$\begin{array}{l}\text { Performs self- } \\
\text { monitoring of } \\
\text { health condition }\end{array}$} & Never demonstrated & 0 & $1(7.1)$ & 0 & 0 & 0 & 0 & \multirow{5}{*}{$<0.001$} \\
\hline & Rarely demonstrated & $5(35.7)$ & $1(7.1)$ & $1(7.1)$ & $1(7.1)$ & 0 & 0 & \\
\hline & Sometimes demonstrated & $4(28.5)$ & $6(42.8)$ & $4(28.5)$ & $3(21.4)$ & $5(35.7)$ & $1(7.1)$ & \\
\hline & Often demonstrated & $1(7.1)$ & $3(21.4)$ & $4(28.5)$ & $2(14.2)$ & $1(7.1)$ & $5(35.7)$ & \\
\hline & Consistently demonstrated & $4(28.5)$ & $3(21.4)$ & $5(35.7)$ & $8(57.1)$ & $8(57.1)$ & $8(57.1)$ & \\
\hline
\end{tabular}

Note: *Testes de Friedman.

Final Score

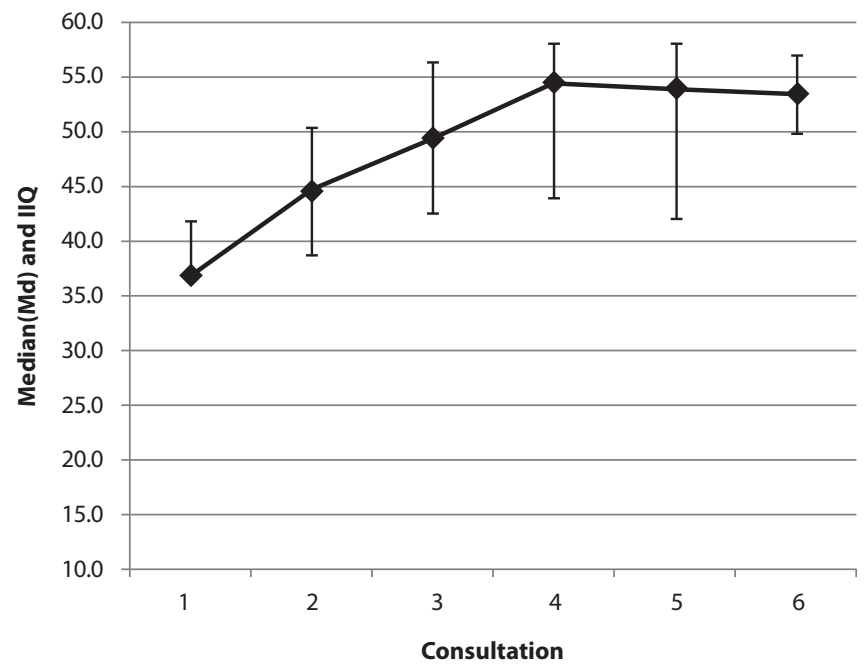

Figure 1 - Variance analysis of the Final Score between in-person consultations, São Paulo, São Paulo, Brazil, 2017

Tables 1 and 2 show that there was an improvement of the magnitude of the indicator when analyzing consultations 1 and 6. All indicators were significant for this analysis, except for the indicator "Uses Strategies to Eliminate Unhealthy Behavior".

In the evaluation of the Final Score, the mean for the six inperson consultations was 47.7 points.
Figure 1 shows the median of the Final Score of each consultation, which obtained a significant improvement between the first and second visits $(p<0.001)$ and the third and fourth visits (p.0.91) in the variance analysis of the Final Score. However, between the fourth and fifth visits (p.0.91) and between the fifth and sixth visits (p.0.23), no significant difference was obtained in the Final Score, proving the stabilization of the result.

\section{DISCUSSION}

The difficulty in complying with the treatment can be understood when analyzing its complexity and, mainly, the resistance to change behavior. Firstly, this change requires, that individuals make a decision that leads to the action of the SC, which entails other actions, such as obtaining knowledge of the disease, making its management and control possible ${ }^{(2)}$.

Therefore, to reach these SC actions, the implementation of interventions that emphasize the acquisition of specific knowledge of the disease, the recognition of signs and symptoms of decompensation and the development of actions that benefit the disease control are fundamental. The NIC interventions "Teaching: Disease Process", "Health Education", and "Cardiac Care" totale 69 activities and have as their main actions the monitoring of patients' health conditions ${ }^{(3)}$.

The NIC intervention "Teaching: Disease Process" was one of the interventions implemented during a study that verified patients' knowledge of HF through two Nursing outcomes and correlated 
the means of their indicators with a knowledge questionnaire of the syndrome within six months after hospital discharge. The results of this study demonstrated the progress of the knowledge about HF and a strong correlation between the classification of the Nursing results and the scores of the knowledge questionnaire, demonstrating the effectiveness of the applied interventions ${ }^{(15)}$.

The NIC intervention "Health Education" was the second most prevalent among interventions considered core to more than eleven clinical specialties ${ }^{(16)}$. Similarly, the NIC "Heart Care" was one of the most widely used interventions in a study investigating NANDA-I, NIC, and NOC, binding to patients with HF in the USA ${ }^{(5)}$.

To evaluate the effectiveness of the Nursing interventions implemented for a given ND, the reduction, modification or elimination of the previously identified related factors must be considered. When there is an alteration in related factors, the patient's condition can be expected to improve, and the intervention implemented is considered successful. When there is no possibility of change in related factors, interventions in the defining characteristics must be focused on ${ }^{(3-4)}$.

The NOC "Compliance Behavior" and "Self-Control of Heart Disease" results and the selected indicators were evaluated in all consultations. For the indicators of "Compliance Behavior", a significant increase in their scores was observed. Positive results of these indicators may be correlated with the broad implementation of the Nursing activities contained in the intervention "Teaching: Disease Process" and "Health Education". In this context, health education is considered a process that improves the knowledge and skills of patients, and influences positive attitudes towards the achievement of favorable health behaviors ${ }^{(17)}$.

Regarding the NOC result "Self-control of Heart Disease", the indicators also showed a significant increase in scores. Research developed with patients with HF and accompanied at home by a home-based follow-up program, selected the referred result as a guide to identify the most appropriate Nursing interventions for the ND "Impaired Comfort", identified in participants ${ }^{(18)}$.

Among the patients from this study, a progressive and significant increase in the scores of the indicator "Limits sodium intake" was evidenced. The positive result of this indicator was related to some activities of the "Health Education" intervention, which was implemented for all patients, aiming at orienting and reinforcing healthy eating habits, with special attention to sodium restriction, as well as the use of alternative natural seasonings to reduce the impact of salt reduction on food.

The expressive compliance with sodium restriction among patients from this study contrasts to the findings of a review article that demonstrated a low compliance rate, ranging from $50 \%$ to $88 \%{ }^{(19)}$. The recommended intake of sodium in the patients' diet with chronic $\mathrm{HF}$ is still controversial due to the lack of studies. Nevertheless, there is evidence that excessive intake of sodium and fluids is associated with the worsening of hypervolemia, constituting a factor of decompensation and risk of hospitalization in patients with symptomatic chronic $\mathrm{HF}^{(20)}$. Thus, for patients with chronic HF, excessive sodium intake must be prevented (at levels $>7 \mathrm{~g}$ of sodium chloride per day) ${ }^{(10)}$.

The indicator "Complies with the recommendation of fluid restriction" obtained a progressive improvement of the score between the first and fourth visits; however, there was no statistical significance $(p<0.050)$. The weakest compliance of patients from this study with respect to this measure can be explained by the fact that fluid restriction (FR) invariably leads to increased thirst, a symptom that is not tolerated by patients with moderate to severe $H F$, associated with the greatest impact on the quality of patient's life, caused by this restriction ${ }^{(21)}$. Fluid restriction has long been considered one of the cornerstones in the management of SC of patients with HF. Nonetheless, this recommendation lacks solid scientific evidence ${ }^{(22)}$. Given the evidence available by the 2018 Brazilian Guideline for Acute and Chronic Heart Failure (Diretriz Brasileira de Insuficiência Cardíaca Crônica e Aguda de 2018), it does not establish specific recommendations on $\mathrm{FR}$ in patients with $\mathrm{HF}^{(10)}$.

Significant improvement in the indicator "Maintains an ideal weight" was evidenced. However, the indicator "Monitors body weight", despite showing progressive improvement, did not have statistical significance. These results can be explained by the fact that patients verbalize the use of parameters, such as the appearance and/or worsening of dyspnea, ascites and extremity edema. Monitoring predictive signs and symptoms of decompensation was expressively addressed using activities of the intervention "Teaching: Disease Process".

There was a significant increase in the scores between consultations of the indicator "Uses medication as prescribed". Contrary results are evidenced in international studies demonstrating reduced compliance with medication in patients with $\mathrm{HF}^{(23)}$.

Regarding the indicators related to vaccination, a significant increase in the scores between the two visits was observed. The positive result of this indicator was related to the activity of the "Education in Health" intervention, which was implemented for all patients to encourage the use of these vaccines. Being vaccinated against influenza (flu) and pneumonia aims, above all, to prevent infection and consequent deterioration of health ${ }^{(24)}$. Data from the literature suggest that annual vaccination against influenza has impacts on reducing hospitalization sickness ${ }^{(25)}$. Vaccination for pneumococcus exhibits less consistent evidence ${ }^{(26)}$. Nevertheless, in the evaluation of risks and benefits, its recommendation was maintained in the latest HF guidelines ${ }^{(10)}$.

The variations in the result scores allow the assessment of implemented care, signaling the changes needed to reach more favorable clinical results based on evidence ${ }^{(27)}$. In this study, when evaluating the behavior of the Final Score resulting from the two NOC results "Self-control of Heart Disease" and "Compliance Behavior", improvement was evidenced from the second face-to-face evaluation with stabilization from the fourth to the last visit, during a one-year follow-up. This finding is in contrast to the evidence that the compliance of patients under chronic conditions usually has a substantial reduction after the first six months of treatment, due to the prolonged and progressive nature of these diseases ${ }^{(28)}$.

As from the fourth consultation, the longer follow-up conducted with these patients managed to separate patients who would need the maintenance of the original consultation scheme from those who would need less frequent encounters, since they had a stable clinical picture.

Thus, it is believed that the outpatient follow-up, guided by the evaluation of the ND "Ineffective Health Control" indicators and through the selected NOC results, favored monitoring the improvement or worsening of the SC. The NIC interventions used for teaching, or as means of strengthening or correcting possible undesirable health behaviors, also contributed to the behavior of SC. 


\section{Study limitations}

This study presents some limitations, such as the short evaluation period, as well as the small sample size, as well as the lack of conceptual and operational definitions of the NOC indicators used in the evaluation, which may result in a subjective evaluation by the nurses.

\section{Contributions to Nursing, Health or Public Policy}

The results of this study make it possible to evaluate the practical applicability of the Nursing process and the NANDA-I, NIC and
NOC taxonomies for HF patients, demonstrating the effectiveness of the interventions for ND "Ineffective Health Control".

\section{CONCLUSIONS}

The results of this study demonstrate that NIC interventions implemented in outpatient care for patients with $\mathrm{HF}$ and the NIC "Ineffective Self-Control of Health" were effective in the evaluation performed through the NOC indicators selected for evaluation. The results suggest that such interventions encourage self-control and health behavior.

\section{REFERENCES}

1. Ponikowski P, Voors AA, Anker SD, Bueno H, Cleland JGF, Coats AJS, et al. 2016 ESC Guidelines for the diagnosis and treatment of acute and chronic heart failure: the task force for the diagnosis and treatment of acute and chronic heart failure of the European Society of Cardiology (ESC). Developed with the special contribution of the Heart Failure Association (HFA) of the ESC. Eur Heart J. 2016;18(8):2129-200. doi: 10.1002/ejhf.592

2. Harkness K, Spaling MA, Currie K, Strachan PH, Clark AM. A systematic review of patient heart failure self-care strategies. J Cardiovasc Nurs. 2015;30(2):121-35. doi: 10.1097/JCN.0000000000000118

3. Carvalho EC, Cruz DALM, Herdman TH. Contribuição das linguagens padronizadas para a produção do conhecimento, raciocínio clínico e prática clínica da Enfermagem. Rev Bras Enferm. 2013;66(esp):134-41. doi: 10.1590/\$0034-71672013000700017

4. Jonkman NH, Westland H, Groenwold RHH, Agren S, Atienza F, Blue L, et al. Do Self-Management Interventions Work in Patients With Heart Failure? An Individual Patient Data Meta-Analysis. Circulation. 2016; 133:1189-98. doi: 10.1161/CIRCULATIONAHA.115.018006

5. Park H. Identifying core NANDA-I nursing diagnoses, NIC interventions, NOC outcomes, and NNN linkages for heart failure. Int J Nurs Knowl. 2014;25(1):30-8. doi: 10.1111/2047-3095.12010

6. Herdman TH; Kamitsuru S. North American Nursing Diagnosis Association. Diagnósticos de enfermagem da NANDA: definições e classificação - 2015-2017. Porto Alegre: Artmed; 2015.

7. Riegel B, Vaughan D, Faukner KM. The situation-Specific Theory of Heart Failure Self-Care. J Cardiovasc Nurs. 2016; 31(3):226-35. doi: $10.1097 / J C N .0000000000000244$

8. Bocchi EA, Arias A, Verdejo H, Diez M, Gómez E, Castro P; Interamerican Society of Cardiology. The reality of heart failure in Latin America. $J$ Am Coll Cardiol. 2013;62(11):949-58. doi: 10.1016/j.jacc.2013.06.013

9. Cavalcante AMRZ, Lopes CT, Brunori EHFR, Swanson E, Moorhead SA, Bachion MM, et al. Self-care behaviors in heart failure. Int J Nurs Knowl. 2018;29(3):146-55. doi: 10.1111/2047-3095.12170

10. Comitê Coordenador da Diretriz de Insuficiência Cardíaca, Rohde LEP, Montera MW, Bocchi EA, Clausell NO, Albuquerque DC, et al. Diretriz Brasileira de Insuficiência Cardíaca Crônica e Aguda. Arq Bras Cardiol. 2018;111(3):436-539. doi: 10.5935/abc.20180190

11. Bos-Touwen I, Jonkman N, Westland H, Schurmans M, Rutten F, de Wit N, Trappenburg J. Tailoring of self-management interventions in patients with heart failure. Curr Heart Fail Rep. 2015;12:223-35. doi: 10.1007/s11897-015-0259-3

12. Maynart WHC, Albuquerque MCS, Breda MZ, Jorge JS. Qualified listening and embracement in psychosocial care. Acta Paul Enferm. 2014;27(4):300-4. doi: 10.1590/1982-0194201400051

13. Ponikowski P, Voors AA, Anker SD, Bueno H, Cleland JGF, Coats AJS, et al. 2016 ESC Guidelines for the diagnosis and treatment of acute and chronic heart failure: The Task Force for the diagnosis and treatment of acute and chronic heart failure of the European Society of Cardiology (ESC)Developed with the special contribution of the Heart Failure Association (HFA) of the ESC. Eur Heart J. 2018;39(10):860. doi: 10.1093/eurheartj/ehw383. Erratum for: Eur Heart J. 2016;37(27):2129-200. doi: 10.1093/eurheartj/ehw128.

14. American Heart Association (AHA). What is heart failure? [Internet]. Dallas: AHA; 2017 [cited 2018 Oct 04]. Available from: https://www.heart. org/en/health-topics/heart-failure/what-is-heart-failure

15. Azzolin KO, Lemos DM, Lucena AF, Rabelo-Silva ER. Home-based nursing interventions improve knowledge of disease and management in patients with heart failure. Rev Latino-Am Enferm. 2015;23(1):44-50. doi: 10.1590/0104-1169.0144.2523

16. Chianca TC, Souza CC, Werli A, Hamze FL, Ercole FF. Uso das intervenções de enfermagem na prática clínica no Brasil1 in Brazil. Rev Elet Enf [Internet]. 2009 [cited 2018 Oct 4];11(3):477-83. Available from: https://www.fen.ufg.br/revista/v11/n3/pdf/v11n3a03.pdf

17. Lakdizaji S, Hassankhni H, Mohajjel Agdam A, Khajegodary M, Salehi R. Effect of educational program on quality of life of patients with heart failure: a randomized clinical trial. J Caring Sci. 2013;2(1):11-8. doi: 10.5681/jcs.2013.002

18. Silva FV. Processo de enfermagem no cuidado clínico de conforto no domicílio para pessoas com insuficiência cardíaca [dissertação] [Internet]. Fortaleza: Universidade Estadual do Ceará; 2013 [cited 2018 Oct 04]. Available from: http://www.uece.br/cmacclis/dmdocuments/ 
Health education: the effectiveness of interventions in patients with heart failure

Oliveira APD, Cavalcante AMRZ, Carneiro CS, Santos VB, Moorhead S, Lopes JL, et al.

FABIOLAVLADIA.pdf

19. Dolansky MA, Schaefer JT, Hawkins MA, Gunstad J, Basuray A, Redle JD, et al. The association between cognitive function and objective adherence to dietary sodium guidelines in patients with heart failure. Patient Prefer Adherence. 2016;10:233-41. doi: 10.2147/PPA.S95528

20. Doukky R, Avery E, Mangla A, Collado FM, Ibrahim Z, Poulin MF, et al. Impact of dietary sodium restriction on heart failure outcomes. JACC Heart Fail. 2016;4(1):24-35. doi: 10.1016/j.jchf.2015.08.007

21. Reilly CM, Higgins M, Smith A, Culler SD, Dunbar SB. Isolating the benefits of fluid restriction in patients with heart failure: a pilot study. Eur J Cardiovasc Nurs. 2015;14(6):495-505. doi: 10.1177/1474515114541729

22. Johansson P, van der Wal MH, Strömberg A, Waldreus N, Jaarsma T. Fluid restriction in patients with heart failure: how should we think? Eur J Cardiovasc Nurs. 2016;15(5):301-4. doi: 10.1177/1474515116650346

23. Davis EM, Packard KA, Jackevicius CA. The pharmacist role in predicting and improving medication adherence in heart failure patients. J Manag Care Spec Pharm. 2014;20(7):741-55. doi: 10.18553/jmcp.2014.20.7.741

24. Acharya D, Uyeki TM. The paradigm of influenza vaccination in heart failure patients. JACC Heart Fail. 2016;4(2):159-61. doi: 10.1016/j. jchf.2015.12.008

25. Mohseni H, Kiran A, Khorshidi R, Rahimi K. Influenza vaccination and risk of hospitalization in patients with heart failure: a self-controlled case series study. Eur Heart J. 2017;38(5):326-33. doi: 10.1093/eurheartj/ehw411

26. Ciszewski A. Cardioprotective effect of influenza and pneumococcal vaccination in patients with cardiovascular diseases. Vaccine. 2018;36(2):202-6. doi: 10.1016/j.vaccine.2017.11.078

27. Azzolin K, Mussi CM, Ruschel KB, Souza EN, Lucena AF, Rabelo-Silva ER. Effectiveness of nursing interventions in heart failure patients in home care using NANDA-I, NIC, and NOC. Appl Nurs Res. 2013;26(4):239-44. doi: 10.1016/j.apnr.2013.08.003

28. Osterberg L, Blaschke T. Adherence to medication. N Engl J Med. 2005;353(5):487-97. doi: 10.1056/NEJMra050100 